\title{
PERAN SEORANG GURU DALAM MENCIPTAKAN LINGKUNGAN BELAJAR YANG KONDUSIF
}

\author{
JUMRAWARSI ${ }^{1}$, NEVIYARNI SUHAILI ${ }^{2}$ \\ ${ }^{1}$ Program Studi Pendidikan Matematika STKIP YDB Lubuk Alung dan Mahasiswa \\ Program Doktor Ilmu Pendidikan Universitas Negeri Padang \\ ${ }^{2}$ Jurusan Bimbingan dan konseling, Fakultas Ilmu Pendidikan, Universitas Negeri \\ Padang \\ jumrawarsi.12@gmail.com, neviyarni.suhaili11@gmail.com
}

\begin{abstract}
Abtract: Conducive learning situation is related to the quality of students learning. The creation of a conducive class will avoid students from feeling bored, psychic exhaustion and also the creation of a conducive class that will provide students motivation and learning convernience. In an active learning condition, students do not feel alone solving cases faced in the learning process, but the students can ask the question to other and discuss each other so that their learning load does not occur. With the existence of an active learning strategy, it is hoped that it can grow all the potential possessed by students so that in the end they can optimize their learning outcomes. hance, The teacher as a guide has very important role in Learning process. Teachers must be able to give students motivation to create a process of interaction that is conducive to the learning process in the classroom. In the interactive teaching and learning process, there is an interaction between students and students and students and teachers.
\end{abstract}

Keywords: Teacher, learning environment and Conducive

Abstrak: Lingkungan belajar yang kondusif sangat berkaitan dengan kualitas belajar peserta didik. Terciptanya kelas kondusif akan menghidari peserta didik dari kejenuhan, kelelahan psikis dan juga terciptanya kelas yang kondusif akan memberikan motivasi dan ketahanan dalam belajar. Dalam lingkungan belajar yang aktif, peserta didik tidak dibebani secara individu dalam menyelesaikan kasus yang dihadapi dalam proses pembelajaran, melainkan peserta didik bisa saling bertanya dan berdiskusi agar beban belajar bagi mereka tidak terjadi. Dengan adanya strategi pembelajaran yang aktif diharapkan dapat menumbuhkan semua potensi yang dimiliki oleh peserta didik sehingga pada akhirnya dapat mengoptimalkan hasil belajarnya. Oleh karena itu, guru sebagai pembimbing sangatlah berperan dalam keberhasilan capaian pembelajaran, Guru hendaknya mampu membangkitkan suasana dan memotivasi peserta didik untuk menciptakan proses interaksi yang kondusif dalam proses pembelajaran di kelas. Dalam proses belajar mengajar yang aktif terjadi interaksi antara peserta didik dengan peserta didik maupun peserta didik dengan guru.

Kata Kunci: Guru, Lingkungan Belajar, kondusif.

\section{A. Pendahuluan}

Sejak lahir anak selalu mengalami pertumbuhan dan perkembangan. Selama proses pertumbuhan, anak tidak statis melainkan dinamis. Dengan adanya sifat dinamis inilah menyebabkan individu itu selalu tumbuh dan berkembang ke arah yang lebih baik, lebih maju dan berbeda dengan sebelumnya. Pertumbuhan dan perkembangan ini terjadi salah satunya pada lingkungan sekolah, lingkungan sekolah inilah yang akan bertanggung jawab menyediakan lingkungan yang dapat 
mendorong pertumbuhan dan perkembangan peserta didik. Menciptakan suatu lingkungan di mana peserta didik selalu terlibat dalam aktifitas yang kondusif adalah tanggung jawab yang besar.

Faktor penentu tercapainya tujuan proses belajar mengajar adalah kemampuan yang dimiliki oleh guru, kurikulum, penggunaan metode pembelajaran, fasilitas prasarana, serta lingkungan pembelajaran baik lingkungan alam, psiko-sosial dan budaya (Depdikbud, 1994). Dengan kata lain lingkungan pembelajaran di sekolah mempunyai pengaruh terhadap tumbuh berkembangannya peserta didik. Bermacam upaya telah dilaksanakan dalam memaksimalkan proses pembelajaran dengan terlaksananya pelatihan dalam rangka meningkatkan

Lingkungan belajar yang kondusif adalah lingkungan belajar di sekolah dalam suasana berlangsungnya interaksi pembelajaran. situasi belajar yang kondusif ini perlu diciptakan dan dipertahankan agar pertumbuhan dan perkembangan peserta didik efektif dan efisien, sehingga tujuan tercapai optimal. Situasi belajar mengajar yang kondusif ini penting dirancang dan diupayakan oleh guru sengaja agar dapat dihindarkan kondisi yang merugikan peserta didik. Permasalahan yang timbul dan perlu dipecahkan bagaimana peran seorang guru dalam meciptakan suasana belajar yang kondusif.

\section{B. Metodologi Penelitian}

Untuk membahas tema tentang suasana belajar sekolah yang kondusif bagi peserta didik, maka dalam hal ini penulis menggunakan metode pembahasan deskrptif naratif yang bermaksud menjelaskan konten atau isi materi secara jelas dan rinci dengan memberikan contoh yang relevan dengan topik.

\section{Hasil dan Pembahasan Pengertian Pengelolan Kelas}

Guru sebagai pendidik. Berperan menyediakan lingkungan belajar yang kondusif yang dapat menyebabkan pertumbuhan dan perkembangan anak agar optimal. Guru bertanggung jawab dalam megelola kelas, bagaimana menciptakan suasana belajar yang kondusif bertujuan tercapainya tujuan pengajaran yang efektif dan efesien. Charles (dalam Santrock : 2008 : 553) menyatakan bahwa Pengelolaan kelas yang efektif akan memaksimalkan kesempatan pembelajaran kepada peserta didik. Kemudian lebih lanjut Santrock menyatakan dalam manajemen kelas menonjolkan pada terciptanya suasana yang aktif.

Kemudian, Slavin (2011:143) menyatakan bahwa pengelolaan ruang kelas atau membuat iklim pembelajaran yang efektif termasuk strategi guru yang digunakan dalam menata ruangan kelas yang positif dan produktif. Strategi tersebut untuk menyediakan lingkungan pembelajaran yang efektif tidak hanya meliputi pencegahan dan tanggapan terhadap perilaku yang buruk tetapi juga, manajemen kelas, membuat suasana yang kondusif. Pendidik yang berkompeten dapat menciptakan suasana proses belajar mengajar yang kondusif dan dapat menstimulus peserta didik ke tahap pembelajaran yang diharapkan. Hughes (1992) mengemukakan karateristik belajar mengajar yang baik yang akan menciptakan suasana belajar yang kondusif: 1) Keinginan untuk berbagi kecintaan kepada peserta didik; 2) Kemampuan guru membuat materi ajar dan mampu membuat ketertarikan; 3) Menfasilitasi/melibatkan diri kepada peserta didik sesuai porsi pemahaman mereka; 4) Kemampuan guru dalam memberikan penjelasan; 5) Memperjelas poin yang meski dimengerti oleh peserta didik; 6) memperlihatkan kepedulian kepada peseta didik; 7) Komitmen untuk Lembaga Penelitian dan Penerbitan Hasil Penelitian Ensiklopedia $\quad 51$ 
mendorong kemandirian peserta didik; 8) Kemampuan untuk meningkatkan dan beradaptasi dengan tidak tutur yang baik; 9) Menggunakan metode mengajar yang menuntut peserta didik manjadi aktif dan memiliki tanggung jawab; 10) Memakai metode penilaian yang valid; 11) Memberikan umpan balik dengan kualitas terbaik pada pekerjaan peserta didik; dan 12) Keinginan untuk belajar dari sumber lain. bagaimana meningkatkan kualitas mengajar.

Karakteristik yang telah kemukakan ini mempunyai kemiripan dengan aspek evaluasi terhadap proses pembelajaran yakni: penyusunan dari rancangan pembelajaran, menimbulkan minat peserta didik, penjelasan yang dapat dimengerti oleh peserta didik, berempati dengan keperluan pelajar, ada umpan balik, tujuan yang jelas, dan menciptakan belajar berfikir. Karakteristik yang paling terakhir dan dirasa penting adalah personaliti pendidik dan rasa humor. Hughes (1992) menyatakan enam prinsip utama belajar mengajar yang berkesan dan menciptakan suasana pembelajaran kondusif, yakni:

1. Minat dan penjelasan, Seperti yang kita ketahui bahwa penjelasan yang jelas tentang isi materi membuat peserta didik merasa tertarik mempelajarinya.

2. Kepedulian dan rasa hormat terhadap peserta didik adalah ciri guru yang baik. sangat penting menhargai dan mempertimbangkan peserta didik dalam membuat proses belajarar mengajar yang terkesan.

3. Penilaian dan umpan balik yang tepat. membuat umpan balik terhadap hasil kerja peserta didik. Peserta didik akan merasa senang jika diberikan evaluasi terhadap karyanya. Sesuai penjelasan Hughes (1992, hlm. 99), Menetapkan tugas yang sesuai dan jelas merupakan keterampilan yang sulit tetapi penting. Ini menyiratkan pertanyaan dengan cara yang menuntut bukti pemahaman, penggunaan berbagai teknik untuk menemukan apa yang telah dipelajari siswa, dan penghindaran dari setiap penilaian yang mengharuskan siswa untuk menghafal atau hanya untuk mereproduksi detail.

4. Tujuan pembelajaran yang jelas dan tantangan intelektual. Sebelum kegiatan proses belajar mengajar dimulai guru hendaknya menjelaskan terlebih dahulu sehingga peserta didik memahami tujuan dari kegiatan tersebut dan juga dalam proses pembelajaran sangat perlu dilaksanakan kegiatan yang menantang intelektual peserta diidk sehingga peserta didik termotivasi untuk mempelajarinya.

5. Kebebasan, pendampingan, dan penglibatan aktif. Pembelajaran yang berkualitas bagi peserta didik terlibat secara aktif, memiliki pilihan terhadap cara mereka belajar dan memiliki pendampingan terhadap aspek yang dipelajari. pengajaran yang baik menumbuhkan rasa kontrol siswa atas pembelajaran dan minat dalam materi pelajaran

6. Belajar dari peserta didik. Idealnya seorang guru berkenan menerima masukan dan melakukan perubahan.

\section{Merancang kelas yang kondusif}

Lingkungan belajar yang kondusif adalah lingkungan belajar di sekolah dalam suasana berlangsungnya proses belajar mengajar. Menurut pendapat Creemers (1999), Manajemen kelas menjadi semakin penting yang diperankan oleh guru, ukuran kelas menjadi penghalang penggunaan strategi dalam mendekatkan diri kepada peserta didik. Oleh katerna itu, dalam pengelolaan kelas yang memuat terkesan, pembelajaran idealnya seperti dibawah ini: 1) Fasilitas/alat, idealnya setiap kelas membutuhkan 
fasilitas, Kelas yang besar akan sulit terlaksana kebutuhan pengajaran contohnya transparensi, mikrofon perlu disediakan sesuai dengan ukuran kela; dan 2) Pembelajaran, dalam proses belajar mengajar guru memastikan kejelasan suara sehiangga bisa terdengar dari belakang oleh peserta didik, untuk berinteraksi dengan peserta didik dalam kelas idealnya fokus pada susunan $U$ tidak seperti susunan $T$, hal ini sangat bermafaat ketika ada interaksi tanya jawab dengan peserta didik.

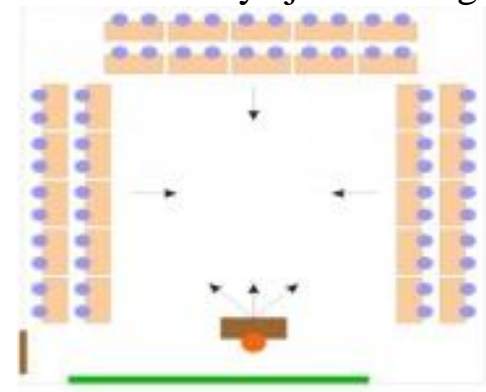

Gambar 1. Model susunan U

1. Tanya jawab, kondisi kelas yang besar dan kelas yang mungil berbeda. guru sebaiknya menjelaskan pada peserta didik mengenai aturan yang akan dilaksanakan, waktu saat pembelajaran. saat guru telah selesai memberi penjelasan, peserta didik diberikan kesempatan bertanya, andai kelas sangat besar, sebaiknya diminta peserta didik menuliskan pertanyaan mereka dikumpulkan dan dibahas satu persatu.

2. Sosialisasi kelas, idealnya hendaknya terjalin hubungan erat antara guru dengan peserta didik hendaknya guru mengaplikasikan langkah di bawah ini: a) Guru Berdiri di hadapan peserta didik, jika ada poin penting yang akan dipahami oleh peserta didik hendaknya guru berdiri dan memberi penekanan suara; b) Berkeliling kelas, jangan hanya berbicara di depan kelas dengan peserta didik. hendaknya yang berdekatan apabila ia kemukakan sebuah pertanyaan. Seorang guru hendaknya menghampiri siswa yang bertanya walupun duduknya dibelakang; c) Hendaknya guru datang ke kelas tepat waktu dan meninggalkan kelas setelah peserta didik keluar semua. Memperbolehkan peserta didik menemui guru dan menanyakan materi yang belum dipahami; dan d) Memasukan unsur lucu yang relevan untuk menghidupkan suasana kelas.

Menurut Mujiyah (1999) menjelaskan lingkungan belajaran yang kondusuf ini perlu dirancang dan diupayakan oleh guru yaitu: 1) Kegiatan mengelola kelas. Kegiatan mengelola kelas sangat erat kaitanya dengan kegiatan pengajaran. Kegiatan pengajaran adalah kegiatan menggiatkan peserta didik, mengidentifikasi kebutuhan peserta didik, menyusun rencana pelajaran yang diawali dengan benar dan jelas materi pelajaran dipilih dan diorganisir sesuai yang akan dicapai.. Apabila kegiatan pengajaran sudah disiapkan oleh guru dengan baik diharapkan suasana belajar dan mengajar menjalan dengan lancar; 2) Pola formasi tapal kuda, susunan ini posisi pendidik berada di tengah peserta didik. Susunan ini cocok digunakan dalam diskusi; dan 3) Pola meja bundar dan persegi (Sri Anitah : 1990). Sangat cocok untuk pembelajaran. Perlu pengaturan kondisi sosio-emosional dalam kelas akan pengaruh yang cukup besar terhadap proses belajar mengajar, terhadap gairah belajar peserta didik dan efektifitas tercapainya tujuan. Guru yang mempunyai posisi penting untuk menciptakan suasana sosio-emosional ini. Sikap guru yang demokratislah yang akan mewarnai suasana emosional kelas. 


\section{Faktor-faktor yang perlu diperhatikan oleh guru.}

Tindakan pencegahan merupakan tindakan yang tepat sebelum munculnya tingkah laku yang menimpang yang dapat menganggu kondisi optimal. Untuk mencegah tindakan yang menimpang selain apa yang telah diuraikan. Perlu memperhatikan faktor-faktor yang sangat berpengaruh: 1) Meningkatkan kesadaran diri sebagai pendidik. jika pendidik menyadari dengan profesinya sebagai guru pada gilirannyaakan meningkatkan rasa tanggung jawab dan rasa memiliki. Menunjukan kepribadian yang stabil, harmonis serta berwibawa. Sikap demikian menimbulkan menghasilkan reaksi serta respon yang positif dari peserta didik; 2) Peningkatan kesadaran peserta didik. Kurangnya kesadaran peserta didik kepada dirinya terlihat dari sikap emosi yang tidak stabil, tersinggung, hal ini akan membuat peserta didik akan melakukan tindakan yang terpuji. Guru harus berupaya menciptakan kesadaran siswa tentang hak dan kewajibanya, menciptakan saling memahami antara pendidik dan peserta didik; dan 3) Sikap tulus dari pendidik, pendidik di harapkan bersikap tulus dan ikhlas, maksudnya dalam kegiatan sehari-hari guru bertindak yang sebenarnya tidak pura-pura. hal ini akan membuat stimulus yang baik bagi peserta didik. Penciptaan suasana sosio-emosional di kelas banyak terpengaruh oleh tindakan seorang pendidik.

\section{Penutup}

Dalam menciptakan lingkungan belajar yang kondusif di kelas hendaknya guru dapat melakukan hal: 1) Merencakan kegiatan pengajaran dengan baik; 2) Menata suasana fisik kelas diantaranya pengaturan ruang kelas dan penyusunan formasi duduk siswa, sehingga dapat memberikan kebebasan bergerak dan kenyamanan untuk belajar; dan 3) Menata lingkungan. Menciptakan iklim sosio-emosional di dalam kelas. Dengan terjadinya hubungan manusiawi, hubungan interpesersonal antara guru dengan siswa dan sebaliknya siswa dengan siswa lainya maka akan memberi suasana bergairah, suasana senang dan tenang untuk belajar. Motifasi belajar akan timbul. Untuk terciptanya ilkmim sosiso-emosional ini guru memegang peran sangat penting. (Sri Anitah : 1990).

\section{Daftar Pustaka}

Creemers, B, Peters, \& ReynoldsD. 1989. School effectiveness and school improvement. Lisse, The Netherland: Swets \& Zeitlinger.

Departemen Pendidikan dan Kebudayaan 1994. Kurikulum Sekolah Lanjutan Tingkat Pertama (SLTP): Petunjuk pelaksanaan proses belajar mengajar. Dikmenum: Jakarta.

Hughes, P. W. 1991. Teachers' professional development. Melbourne, Victoria: Australian Council for Educational Research.

Mujiyah (1999). Menciptakan lingkungan belajar yang kondusif bagi pertumbuhan dan perkembangan peserta didik. Dinamika pendidikan no.1 vol 4.

Santrock, John W. 2008. Psikologi Pendidikan: Edisi Kedua. Jakarta: Kencana.

Slavin. 2011. Psikologi Pendidikan: Teori dan Praktik: Edisi Kesembilan. Alih Bahasa Marianto Samosir. Jakarta: PT Indeks.

Sri anitah W, Noorhadi (1990) Strategi Belajar Mengajar. Jakarta: Universitas Terbuka. 